\title{
Detection and complete genome characterization of begomovirus infecting okra (Abelmoschus esculentus) in Brazil
}

\author{
Silvia de Araujo Aranha ${ }^{1}$, Leonardo Cunha de Albuquerque ${ }^{1}$, Leonardo Silva Boiteux ${ }^{2}$ \& Alice Kazuko \\ Inoue-Nagata $^{2}$
}

${ }^{1}$ Departamento de Fitopatologia, Universidade de Brasília, 70910-900, Brasília, DF, Brazil; ${ }^{2}$ Embrapa Hortaliças, 70359970, Brasília, DF, Brazil

Author for correspondence: Alice K. Inoue-Nagata, e-mail. alicenag@cnph.embrapa.br

\begin{abstract}
A survey of okra begomoviruses was carried out in Central Brazil. Foliar samples were collected in okra production fields and tested by using begomovirus universal primers. Begomovirus infection was confirmed in only one (\#5157) out of 196 samples. Total DNA was subjected to PCR amplification and introduced into okra seedlings by a biolistic method; the bombarded DNA sample was infectious to okra plants. The DNA-A and DNA-B of isolate \#5157 were cloned and their nucleotide sequences exhibited typical characteristics of New World bipartite begomoviruses. The DNA-A sequence shared 95.6\% nucleotide identity with an isolate of Sida micrantha mosaic virus from Brazil and thus identified as its okra strain. The clones derived from \#5157 were infectious to okra, Sida santaremnensis and to a group of Solanaceae plants when inoculated by biolistics after circularization of the isolated insert, followed by rolling circle amplification.
\end{abstract}

Key words: Sida micrantha mosaic virus, geminivirus, SimMV.

\section{RESUMO}

Deteç̧ão e caracterização do genoma completo de um begomovírus que infecta o quiabeiro (Abelmoschus esculentus) no Brasil

Um levantamento de begomovírus de quiabeiro foi realizado no Brasil Central. Amostras foliares foram coletadas em campos de produção de quiabo e avaliadas em testes utilizando primers universais para begomovírus. A infecção por begomovírus foi confirmada em apenas uma amostra (\#5157) de um total de 196 amostras. O DNA total foi submetido à amplificação por PCR e introduzido em plântulas de quiabeiro pelo método de biobalística, sendo que a amostra de DNA bombardeada foi infecciosa em plantas de quiabeiro. O DNA-A e DNA-B do isolado \#5157 foram clonados e a sequência de nucleotídeos mostrou características típicas de begomovírus do Novo Mundo. A sequência do DNA-A apresentou 95,6\% de identidade nucleotídica com um isolado de Sida micrantha mosaic virus do Brasil, sendo assim identificado como sua estirpe de quiabeiro. Os clones gerados a partir da amostra \#5157 foram infecciosos para quiabeiro, Sida santaremnensis e em um grupo de plantas solanáceas quando inoculados por biobalística após circularização do inserto isolado, seguido por amplificação por círculo rolante.

Palavras-chave: Sida micrantha mosaic virus, geminivírus, SimMV.

\section{INTRODUCTION}

The genus Begomovirus (family Geminiviridae) consists of an emergent group of plant viruses that cause economically important crop diseases in tropical and subtropical regions (Zerbini et al., 2005). Begomoviruses are characterized by a single-stranded DNA genome, encapsulated within a typical geminated particle, and are transmitted by the whitefly Bemisia tabaci (Gennadius) to dicotyledonous plants (Fauquet \& Stanley, 2005). The Brazilian begomoviruses are typically bipartite containing both DNA-A and DNA-B components (Andrade et al., 2006; Fernandes et al., 2006; Ribeiro et al., 2007; Albuquerque et al., 2010). Since the 1960's several begomovirus species have been found causing mosaic diseases in many host species in Brazil, including Malvaceous plants (Zerbini et al., 2005). It was believed that a mosaic disease that affected okra (Abelmoschus esculentus L. Moench) production was caused by a begomovirus (Kitajima et al., 1979). This disease was known as "infectious chlorosis of malvaceous plants", but its etiology was not definitively confirmed.

Breeding efforts carried out to control this okra mosaic disease resulted in the development of the okra variety 'Santa Cruz 47' (Sudo et al., 1974), with effective levels of field resistance to the causal agent(s) prevalent in the country at that time. After the release of the resistant cultivar 'Santa Cruz 47', mosaic diseases on okra production decreased in their importance (Nagai, 1993). More recently, however, the B. tabaci biotype B was introduced into the country (Lourenção \& Nagai, 1994; França et al., 1996) 
Detection and complete genome characterization of a begomovirus infecting okra...

and new okra cultivars and hybrids have been gradually used together with 'Santa Cruz 47'. In this new situation, okra plants with mosaic and chlorotic spots were again observed in some growing areas of the Federal District and Goiás State in Central Brazil, indicating that the evolutionary process of begomovirus adaptation to okra is underway. In the present report, we carried out the complete genomic analysis of a begomovirus isolate obtained from symptomatic leaf samples in order to identify the causal agent of the okra mosaic disease under Brazilian conditions.

\section{MATERIALS AND METHODS}

\section{Virus collection and detection test}

From April 2007 to February 2008, several okra production fields were visited in Central Brazil (Federal District and Goiás State) and 196 samples were collected from either asymptomatic plants or from plants showing chlorotic spots and mosaic symptoms. Total DNA was extracted and tested by PCR amplification using begomovirus universal primers pAR1c496 and pAL1v1978 (Rojas et al., 1993).

\section{Biolistic inoculation}

To confirm the presence of begomoviruses able to infect okra plants in the sample, biolistic inoculation of the rolling circle amplified total DNA preparation was done on healthy okra seedlings. For this purpose, initially total DNA of the sample was subjected to rolling circle amplification (RCA) to increase the amount of viral DNA in the preparation. The RCA method can amplify circular DNA by a rolling circle mechanism, generating a high population of mostly double stranded DNA with high molecular weight. This viral genome-enriched DNA preparation was introduced into eight okra 'Santa Cruz 47' seedlings with two-three true leaves by biolistic inoculation (Aragão et al., 1995). Three weeks after inoculation, total DNA was extracted and subjected to PCR amplification using begomovirus universal primers (Rojas et al., 1993).

\section{Cloning, sequencing and sequence analysis}

For cloning of the complete genome, total DNA subjected to RCA was digested with ClaI (DNA-A) and SacI (DNA-B) restriction endonucleases for isolation of monomeric units of the genome and cloned into pBluescript II SK+ (Stratagene) using a standard protocol for geminivirus cloning (Inoue-Nagata et al., 2004). Clones were selected, the plasmid DNA purified by QIAprep Spin Miniprep Kit (QIAGEN) and completely sequenced at Macrogen Inc., Korea. The complete nucleotide sequence was assembled using the Staden Package (Staden, 2003) and compared with other sequences available in public databases using Clustal V algorithm (Higgins et al., 1992) included in MegAlign software (DNAStar Inc., Madison, WI, USA). The DNA-A and DNA-B component sequences of other bipartite begomoviruses were retrieved from public data bases, aligned and used for generation of phylogenetic trees constructed using Mega 4.0 (Tamura et al., 2007).

\section{Experimental host range}

For preparation of infectious clones, DNA-A and DNA-B clones were digested with ClaI and SacI, respectively, to isolate the genomic DNA fragments. These $2.6 \mathrm{~kb}$ fragments were recircularized using T4 DNA-ligase and amplified by RCA; both components were mixed and inoculated by biolistics in plant species of the families Malvaceae, Solanaceae, Chenopodiaceae, Asteraceae, and Euphorbiaceae. Plants were daily evaluated for symptom expression up to 30 days postinoculation. Three weeks after inoculation, the total DNA was extracted and subjected to PCR using the primers described above to confirm infection on each plant.

\section{RESULTS}

\section{Detection of begomovirus in okra plants}

Among the collected 196 symptomatic or asymptomatic plants, only one sample (\#5157) was found to be positive by PCR, producing a DNA fragment of ca. $1.4 \mathrm{~kb}$. Sample \#5157 was collected at Goianápolis, GO (GPS coordinates 16³0'24.09'S, 4901'19.82'W, 984m altitude, on April 12, 2007). The symptomatic plant showed chlorotic spots and mottling (Figure 1A).

\section{Infectivity of okra begomoviruses}

The infectivity of the begomovirus present in the sample could be confirmed by inoculation of total DNA amplified by RCA and later tested by PCR. Infected plants were either asymptomatic or developed chlorotic spots, mottling, and mild blistering (Figure 1B). This test demonstrated that a begomovirus was present in the okra plant and that it could infect healthy plants by biolistics.

\section{Complete genome analysis}

The complete genome sequence of the begomovirus isolate obtained from naturally-infected okra plants was determined after cloning the genomic DNA components using the RCA method. Two clones were sequenced for each viral genome component. As these clones were more than $99 \%$ identical to each other for both components, DNA-A clone 15 (5157-15A) and DNA-B clone 1 (51571B) were selected for further analyses. The complete DNAA and DNA-B sequences of \#5157 were determined to be 2684 (accession number EU908733) and 2653 (accession number EU908734) nucleotides long, respectively. The DNA-A encodes one open reading frame (ORF AV1 or CP) in the viral sense DNA and four ORFs (AC1 (or Rep), AC2 (or Trap), AC3 (or REn) and AC4) in the complementary sense. The DNA-B encodes two ORFs, one in the viral sense (BV1 or NSP) and another in the complementary sense (BC1 or MP). Both components showed an intergenic region and a common region of 178 nucleotides with $97.2 \%$ identity, which includes the conserved nonanucleotide 

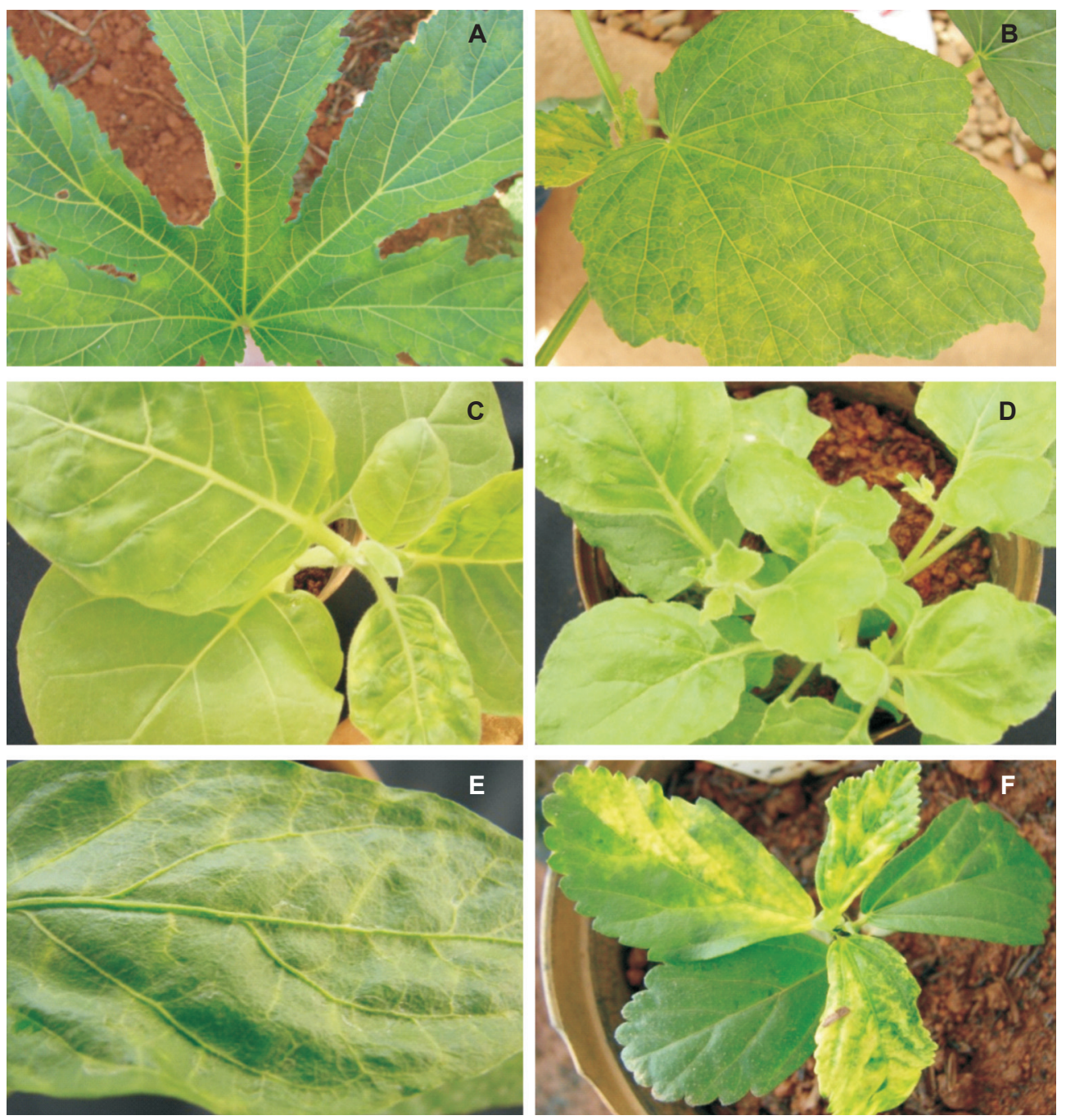

FIGURE 1 - A. okra leaf with chlorotic lesions in an okra production field; B. okra plant inoculated by biolistics with rolling circle amplified viral DNA of isolate \#5157 showing chlorotic lesions, mottling and mild blistering; \#5157 derived clones were infectious to C. N. tabacum, leaf distortion, interveinal chlorosis, blistering; D. N. benthamiana, interveinal chlorosis, mild leaf distortion; E. Capsicum annum "Ikeda", vein yellowing, leaf distortion and F. Sida santaremnensis, yellow mosaic.

sequence TAATATT $\downarrow$ AC typical of geminiviruses (HanleyBowdoin et al., 2000).

A phylogenetic tree was constructed and the branch containing the \#5157 sequence and closely related sequences is shown in figure 2. The DNA-A sequence of \#5157 was most closely related to those described for Sida micrantha mosaic virus (SimMV) and an okra infecting virus (undescribed Brazilian begomovirus) and more distantly related to all Sida-infecting begomoviruses from Brazil. This cluster was also composed of a group of recently reported tomato viruses (Castillo-Urquiza et al., 2008) (Figure 2A). The phylogenetic tree of DNA-B confirmed the close relationship of isolate \#5157 with SimMV isolates (Figure 2B).

Sequence comparisons with other begomoviruses (Table 1) revealed that the DNA-A of isolate \#5157 shared
92.4 to $95.6 \%$ nucleotide sequence identity with those reported for SimMV, while DNA-B sequence shared 84.9 to 94.0\% with SimMV sequences. Sida micrantha mosaic virus isolates were first isolated from Sida micrantha A.St.-Hill. [synonym of Sidastrum micranthum (A.St.-Hil.) Fryxell] plants (Jovel et al., 2007; Jovel et al., 2004). The infectivity of these SimMV isolates to okra plants is currently not known. Therefore, isolate \#5157 was considered as the okra strain of SimMV.

\section{Infectivity of DNA-A and DNA-B clones of the \#5157 isolate}

When inoculated together by biolistics, DNA-A and DNA-B clones were infectious to okra, Sida santaremnensis H. Monteiro (Figure 1F) and some Solanaceae plants (Table 2, Figure 1). From 106 inoculated okra plants, 
Detection and complete genome characterization of a begomovirus infecting okra...
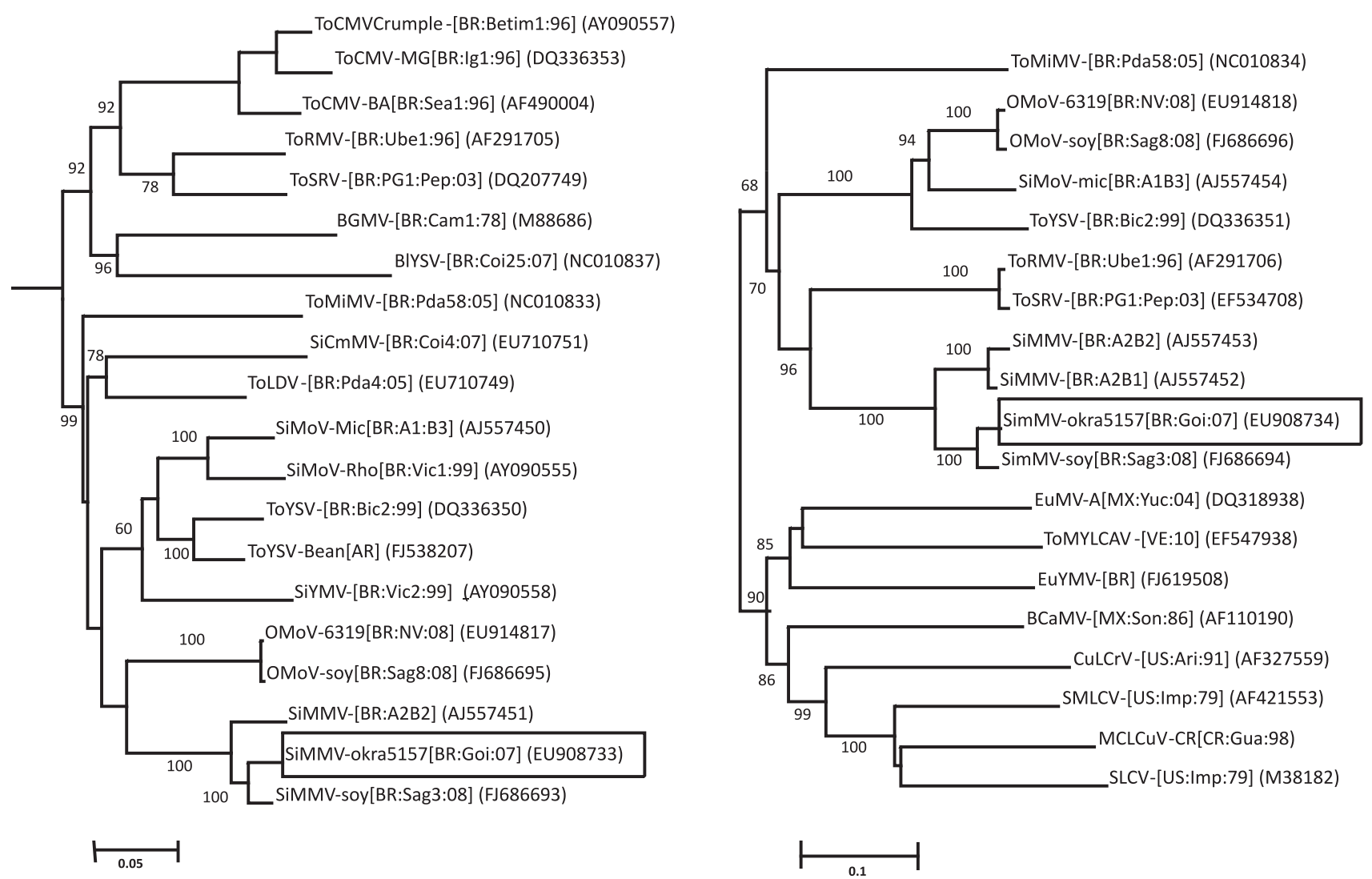

FIGURE 2 - Phylogenetic tree of DNA-A (A) and DNA-B (B) sequence from okra begomovirus sequences and other closely related begomoviruses. The DNA sequence of Tomato yellow leaf curl Thailand virus (TYLCTHV), a divergent begomovirus from Thailand, was used as an outgroup. The trees were constructed by the neighbor-joining method using Mega 4.0 program (Tamura et al., 2007) and condensed to show only clusters with $50 \%$ bootstrap (1,000 replicates) support. GenBank accession numbers are shown in the tree.

only two became infected; while cv. Clemson 80 showed chlorotic spots, cv. Santa Cruz 47 was symptomless. This low infection rate suggested that these cultivars have some degree of resistance to SimMV \#5157 infectious clones. Tomato (Solanum lycopersicum L.), Datura metel L., and Solanum americanum Mill. were not infected, but Nicotiana benthamiana Domin. (Figure 1D) and N. tabacum L. (Figure 1C) were easily infected in this assay by the SimMV \#5157 isolate. The symptom of sweet pepper (Capsicum annuum L.) was evident with strong yellowing of the leaf veins (Figure 1E).

\section{DISCUSSION}

Okra plants are susceptible to at least eight begomovirus species worldwide: Abutilon mosaic virus, Bhendi yellow mosaic virus, Okra yellow crinkle virus, Okra yellow mosaic Mexico virus, Okra yellow mottle Iguala virus, Okra yellow vein mosaic virus, Pepper golden mosaic virus, and Pepper huasteco yellow vein virus (Fauquet et al., 2008). In Brazil, there is so far no report of begomoviruses causing problems on cultivated malvaceous crops, but solely on weeds, including Sida and
Sidastrum species. These plants, designated here as Sidalike plants, are commonly found throughout the country, and frequently display strong yellow mosaic symptoms. Begomoviruses are invariably detected on these plants and this demonstrates the intimate association of begomoviruses with Sida-like plants. On the other hand, okra and cotton plants are two important malvaceous crops in Brazil with no previous report in begomovirus epidemics, in sharp contrast with the situation observed in Asia (Hameed et al., 1994; Briddon \& Markham, 2000; Briddon, 2003; Kirthi et al., 2004). The initial breeding effort to incorporate resistance to begomovirus done in the early 1970's may explain the lack of reports of begomoviruses on okra plants in Brazil. It is likely that the previous breeding program aiming to incorporate virus resistance into okra (Sudo et al., 1974) was effective in preventing the outbreak of begomoviruses in Brazil, since the Santa Cruz 47 variety is one of the most used in the country since its release. Clemson 90, another cultivar, was not easily infected either, but at a higher rate than Santa Cruz 47 in this trial. The infrequent detection of okra begomovirus might reflect this low infectivity, but the high virus pressure and frequent occurrence of genomic recombination among begomoviruses present in Brazilian 
S.A. Aranha et al.

TABLE 1 - Comparison of \#5157 DNA-A and DNA-B nucleotide sequence with the closest begomoviruses

\begin{tabular}{lcccc}
\hline \hline Virus ${ }^{a}$ [isolate] & DNA-A (\%) & DNA-B (\%) & Accession (DNA-A) & Accession (DNA-B) \\
\hline SimMV-[BR:Sag3:Soy:08] & 95.6 & 94.0 & FJ686693 & FJ686694 \\
SimMV-[BR:A2B2] & 93.4 & 86.1 & AJ557451 & AJ557453 \\
OMoV-[BR:Sag8:Soy:08] & 82.2 & 72.3 & FJ686695 & FJ686696 \\
OMoV-6319[BR:NV:08] & 82.2 & 70.4 & EU914817 & EU914818 \\
SiMoV-mic[BR:A1B3] & 77.8 & 60.4 & AJ557450 & AJ557454 \\
ToYSV-[BR:Bic2:99] & 74.9 & 57.3 & DQ3336350 & DQ336351 \\
SiYMV-[BR:Vic2:99] & 73.8 & nd & AY090558 & - \\
ToLDV-[BR:Pda4:05] & 78.7 & nd & EU710749 & - \\
SiMoV-Rho[BR:Vic1:99] & 76.6 & nd & AY090555 & - \\
ToMiMV-[BR:Pda58:05] & 73.9 & 56.8 & NC_010833 & NC010834 \\
ToYSV-Bean[AR] & 77.0 & nd & FJ538207 & - \\
BGMV-[BR:Cam1:78] & 70.7 & 52.6 & M886866 & M886687 \\
ToRMV-[BR:Ube1:96] & 73.4 & 62.6 & AF291705 & AF291706 \\
ToCMV-Crumple[BR:Betim1:96] & 68.3 & nd & AY090557 & - \\
SiCmMV-[BR:Coi4:07] & 71.4 & nd & EU710751 & - \\
ToCMV-BA[BR:Sea1:96] & 69.8 & 52.6 & AF490004 & AF491306 \\
ToCMV-MG[BR:Ig1:96] & 68.6 & 50.7 & DQ336353 & DQ336354 \\
ToSRV-[BR:PG1:Pep:03] & 73.7 & 61.6 & DQ207749 & EF534708 \\
BlYSV-[BR:Coi25:07] & 64.9 & 49.7 & NC_010837 & NC_010838 \\
SimMV-[BR:A2B1] & nd & 87.4 & nd & AJ557452 \\
AbMBV & 68.3 & 58.3 & FN434438 & FN434439 \\
EuMV-[MGS1:07] & 62.0 & 51.9 & FN435995 & FN435996 \\
EuMV-[MGS2:07] & 61.7 & 51.0 & FN435997 & FN435998 \\
ClLCrV & 66.5 & 50.7 & FN435999 & FN436000 \\
SiMBV & 74.7 & 56.9 & FN436001 & FN436002 \\
SimMV-[MGS1:07] & 93.5 & 85.5 & FN436003 & FN436004 \\
SimMV-[MGS2:07] & 92.4 & 84.9 & FN436005 & FN436006 \\
\hline
\end{tabular}

${ }^{a}$ Acronym: SimMV (Sida micrantha mosaic virus), OMoV (Okra mottle virus), SiMoV (Sida mottle virus), ToYSV (Tomato yellow spot virus), SiYMV (Sida yellow mosaic virus), ToLDV (Tomato leaf distortion virus), ToMiMV (Tomato mild mosaic virus), BGMV (Bean golden mosaic virus), ToRMV (Tomato rugose mosaic virus), ToCMV (Tomato chlorotic mottle virus) SiCmMV (Sida common mosaic virus), ToSRV (Tomato severe rugose virus), BlYSV (Blainvillea yellow spot virus), AbMBV (Abutilon mosaic Brazil virus), EuMV (Euphorbia mosaic virus), ClLCrV (Cleome leaf crumple virus), SiMBV (Sida mosaic Brazil virus).

TABLE 2 - Experimental host range of \#5157 infectious clones inoculated by biolistic

\begin{tabular}{lcc}
\hline \hline Inoculated host & Infectivity $^{\mathbf{a}}$ & Symptoms $^{\mathbf{b}}$ \\
\hline Malvaceae & & - \\
\hline A. esculentus (L.) Moench Santa Cruz 47 & $1 / 98$ & CS \\
A. esculentus Clemson 80 & $1 / 8$ & LD, M \\
Sida santaremnensis H. Monteiro & $7 / 12$ & \\
Solanaceae & & VY, LR, Mo \\
Capsicum annuum L. 'Ikeda' & $2 / 8$ & LD, M \\
C. chinense Jacquin. 'PI 159236' & $2 / 8$ & - \\
Datura metel L. & $0 / 8$ & LD, M \\
D. stramonium L. & $3 / 8$ & LD, NS, Mo \\
Nicandra physaloides L. Gaertn. & $3 / 8$ & LD, CL, Mo \\
Nicotiana benthamiana Domin. & $14 / 20$ & LD, M \\
N. rustica L. & $2 / 8$ & $\mathrm{mB}, \mathrm{LD}, \mathrm{VB}, \mathrm{CS}$ \\
N. tabacum L. 'TNN' & $4 / 4$ & LD, M \\
Physalis pubescens L. & $2 / 8$ & - \\
Solanum americanum Mill. & $0 / 8$ & - \\
S. lycopersicum L. 'Santa Clara' & $0 / 8$ & \\
\hline
\end{tabular}

aNumber of infected plants by \#5157 clones (PCR positives) / number of inoculated plants.

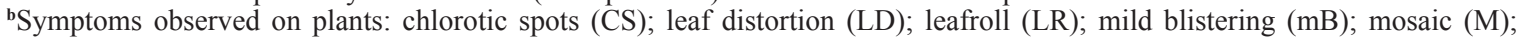
mottling (Mo); necrotic spots (NS); vein banding (VB); vein yellowing (VY); asymptomatic (-). 
Detection and complete genome characterization of a begomovirus infecting okra...

cultivated or non-cultivated areas may eventually result in resistance breakdown and potentially serious problems in okra cultivation in Brazil.

As expected, the sequence analysis of \#5157 clones showed a genomic organization typical of the Western Hemisphere begomoviruses, with a bipartite nature. According to the currently accepted begomovirus classification criteria (Fauquet et al., 2008), \#5157 derived virus is considered to belong to Sida micrantha mosaic virus - an okra strain hereafter designated as Sida micrantha mosaic virus-okra5157[Brazil:Goianápolis:2007], acronym SimMV-okra5157[BR:Goi:07].

This is the first formal report of a begomovirus on okra and the first study to present the complete genomic sequence of a begomovirus infecting okra in Brazil. This isolate was able to systemically infect Solanaceae and Malvaceae plants by biolistics. These clones were also able to induce similar symptoms previously reported in plants with "infectious chlorosis of malvaceous plants", which suggests that they could be the etiologic agent associated with the okra mosaic disease reported previously in Brazil. Furthermore, we were able to demonstrate that rolling circle amplified total DNA can be infective after introduction through biolistics and that re-circularization of cloned viral insert is an easy and fast method to produce infectious clones, and thus facilitate the fulfillment of "Koch's Postulates" for begomoviruses.

\section{ACKNOWLEDGMENTS}

The authors are grateful for the technical assistance of Oneilson Medeiros de Aquino, Lucio Flávio Barbosa, and Hamilton José Lourenço. This study was supported by grants from Embrapa and Conselho Nacional de Pesquisa e Desenvolvimento - CNPq. Alice K. Inoue-Nagata is a CNPq fellow.

\section{REFERENCES}

Albuquerque LC, Martin DP, Avila AC, Inoue-Nagata AK (2010) Characterization of tomato yellow vein streak virus, a begomovirus from Brazil. Virus Genes 40:140-147.

Andrade EC, Manhani GG, Alfenas PF, Calegario RF, Fontes EPB, Zerbini FM (2006) Tomato yellow spot virus, a tomato-infecting begomovirus from Brazil with a closer relationship to viruses from Sida sp., forms pseudorecombinants with begomoviruses from tomato but not from Sida. Journal of General Virology 87:36873696.

Aragão FJL, Brasileiro ACM, Ribeiro SG, Faria JC, Rech EL (1995) Inoculation of bean and soybean with cloned bean golden mosaic virus (BGMV) DNA using particle acceleration. Fitopatologia Brasileira 20:642-644.

Briddon RW (2003) Cotton leaf curl disease, a multicomponent begomovirus complex. Molecular Plant Pathology 4:427-434.

Briddon RW, Markham PG (2000) Cotton leaf curl virus disease.
Virus Research 71:151-159.

Castillo-Urquiza GP, Bezerra Jr. JEA, Bruckner FP, Lima ATM, Varsani A, Alfenas-Zerbini P, Zerbini FM (2008) Six novel begomoviruses infecting tomato and associated weeds in Southeastern Brazil. Archives of Virology 153:1985-1989.

Fauquet CM, Briddon RW, Brown JK, Moriones E, Stanley J, Zerbini M, Zhou X (2008) Geminivirus strain demarcation and nomenclature. Archives of Virology 153:783-821.

Fauquet CM, Stanley J (2005) Revising the way we conceive and name viruses below the species level: A review of geminivirus taxonomy calls for new standardized isolate descriptors. Archives of Virology 150:2151-2179.

Fernandes JJ, Carvalho MG, Andrade EC, Brommonschenkel SH, Fontes EPB, Zerbini FM (2006) Biological and molecular properties of Tomato rugose mosaic virus (ToRMV), a new tomatoinfecting begomovirus from Brazil. Plant Pathology 55:513-522.

França FH, Villas-Boas GL, Castelo Branco M(1996) Ocorrência de bemisia argentifolii Bellows \& Perring (Homoptera: Aleyrodidae) no Distrito Federal. Anais da Sociedade Entomológica do Brasil 25:369-372.

Hameed S, Khalid S, Ulhaq E, Hashrni AA (1994) Cotton leaf curl disease in Pakistan caused by a whitefly-transmitted geminivirus. Plant Disease 78:529-529.

Hanley-Bowdoin L, Settlage SB, Orozco BM, Nagar S, Robertson D (2000) Geminiviruses: Models for plant DNA replication, transcription, and cell cycle regulation. Critical Reviews in Biochemistry and Molecular Biology 35:105-140.

Inoue-Nagata AK, Albuquerque LC, Rocha WB, Nagata T (2004) A simple method for cloning the complete begomovirus genome using the bacteriophage $\varphi 29$ DNA polymerase. Journal of Virological Methods 116:209-211.

Jovel J, Preiss W, Jeske H (2007) Characterization of DNA intermediates of an arising geminivirus. Virus Research 130:63-70.

Jovel J, Reski G, Rothenstein D, Ringel M, Frischmuth T, Jeske $\mathrm{H}$ (2004) Sida micrantha mosaic is associated with a complex infection of begomoviruses different from Abutilon mosaic virus. Archives of Virology 149:829-841.

Kirthi N, Priyadarshini CGP, Sharma P, Maiya SP, Hemalatha V, Sivaraman P, Dhawan P, Rishi N, Savithri HS (2004) Genetic variability of begomoviruses associated with cotton leaf curl disease originating from India. Archives of Virology 149:20472057.

Kitajima EW, Noda H, Lin MT, van der Pahlen A (1979) Levantamento preliminar de vírus de plantas cultivadas nos arredores de Manaus, AM. Acta Amazônica 9:633-640.

Lourenção AL, Nagai H (1994) Surtos populacionais de Bemisia tabaci no Estado de São Paulo. Bragantia 53:53-59.

Ribeiro SG, Martin DP, Lacorte C, Simoes IC, Orlandini DR, InoueNagata AK (2007) Molecular and biological characterization of tomato chlorotic mottle virus suggests that recombination underlies the evolution and diversity of Brazilian Tomato Begomoviruses. Phytopathology 97:702-711.

Rojas MR, Gilbertson RJ, Russell DR, Maxwell DP (1993) Use of degenerate primers in the polymerase chain-reaction to detect whitefly-transmitted geminiviruses. Plant Disease 77:340-347.

Sudo S, Ribeiro RLD, Kimura O, Akiba F, Robbs CF (1974) Santa 


\section{S.A. Aranha et al.}

Cruz-47, nova variedade de quiabeiro (Hibiscus esculenta L.) com resistência a doenças prevalentes na Baixada Fluminense. Fitopatologia Brasileira 9:72-73.

Tamura K, Dudley J, Nei M, Kumar S (2007) MEGA4: Molecular Evolutionary Genetics Analysis (MEGA) software version 4.0.
Molecular Biology and Evolution 24:1596-1599.

Zerbini FM, Andrade EC, Barros DR, Ferreira SS, Lima ATM, Alfenas PF, Mello RN (2005) Traditional and novel strategies for geminivirus management in Brazil. Australasian Plant Pathology $34: 475-480$

TPP 222 - Received 2 December 2010 - Accepted 2 February 2011 